\title{
Deteç̧ão de genes do cluster egc em Staphylococcus aureus isolados de alimentos de origem animal
}

\author{
Detection of genes of egc cluster in Staphylococcus aureus isolated from foods of animal origin
}

\author{
Fernando Zocche ${ }^{\mathrm{I}}$ Caroline Peixoto Bastos ${ }^{\mathrm{II}}$ Wladimir Padilha da Silva ${ }^{\mathrm{II}}$
}

\section{RESUMO}

Os objetivos deste estudo foram detectar, por PCR, genes codificadores de enterotoxinas estafilocócicas, pertencentes ao cluster egc (genes seg, sei, selm, seln e selo) em Staphylococcus aureus isolados em diferentes alimentos de origem animal, e relacionar sua presença com a fonte de isolamento. Quarenta e uma cepas de $\boldsymbol{S}$. aureus de diferentes origens (carne de frango, leite cru, embutidos cárneos e queijo) foram avaliadas por PCR, por meio da amplificação de um fragmento de $3375 \mathrm{pb}$ (denominado egc parcial), que foi utilizado como marcador da presença do cluster, e fragmentos de cada um dos genes pertencentes ao cluster egc. Há presença de genes do cluster egc em isolados de S. aureus isoladas em alimentos de origem animal; entretanto, diferentes genótipos puderam ser observados em função da fonte de isolamento. A ocorrência de S. aureus isolados em carne de frango que possuíam todos os genes do cluster foi elevada; no entanto, nos isolados oriundos dos demais alimentos, essa ocorrência foi reduzida.

Palavras-chave: cluster de genes, enterotoxinas estafilocócicas, contaminação, produtos de origem animal, PCR.

\section{ABSTRACT}

The aim of this study was to detect, through PCR usage, the genes which encodes staphylococcal enterotoxins and which belongs to egc cluster (seg, sei, selm, seln and selo) in $\boldsymbol{S}$. aureus isolated from different foods of animal origin and correlate their presence with the strain origin. Forty-one strains of $\boldsymbol{S}$. aureus from different sources (chicken meat, raw milk, sausage meat and cheese) were evaluated through PCR by amplifying a fragment of $3375 b p$ (called partial egc), which was used as a marker for the presence of cluster, and fragments of individual genes belonging to egc cluster. There is presence of the egc cluster in strains of $\boldsymbol{S}$. aureus isolated from foods of animal origin, however, different genotypes could be observed depending on the isolation source. The occurrence of strains isolated from chicken meat that had all the genes of the cluster was high; however, in the strains isolated from the other foods, such occurrence has been reduced.

Key words: egc cluster, staphylococcal enterotoxins, contamination, foods of animal origin, PCR.

\section{INTRODUÇÃO}

O gênero Staphylococcus é formado por 41 espécies e 24 subespécies (EUZÉBY, 2009). Entre as bactérias desse gênero, $S$. aureus é a mais relacionada a casos e a surtos de intoxicação alimentar em razão da sua capacidade de produzir enterotoxinas (EE) (CENCIGOGA et al., 2003). Vinte e duas EE já foram descritas e 10 foram envolvidas com intoxicação alimentar (EEA, $\mathrm{EEB}, \mathrm{EEC}_{1}, \mathrm{EEC}_{2}, \mathrm{EEC}_{3}, \mathrm{EED}, \mathrm{EEE}, \mathrm{EEG}, \mathrm{EEH}$ e EEI) (CENCI-GOGA et al., 2003). Embora a maioria dos casos e surtos de intoxicação alimentar estafilocócica seja atribuída às EE clássicas (EEA à EEE) (CHEN et al., 2004), o recente avanço dos métodos de diagnóstico permitiu a identificação de casos de intoxicação alimentar envolvendo EEG, EEH e EEI, indicando que a importância das "novas" EE pode estar sendo subestimada (CHEN et al., 2004; CENCI-GOGA et al., 2003).

${ }^{\mathrm{I} C o l e g i a d o ~ d e ~ M e d i c i n a ~ V e t e r i n a ́ r i a, ~ U n i v e r s i d a d e ~ F e d e r a l ~ d o ~ V a l e ~ d o ~ S a ̃ o ~ F r a n c i s c o ~(U N I V A S F), ~ R o d o v i a ~ B R ~ 407, ~ k m ~ 12, ~ L o t e ~ 543, ~}$ 56300-990, Petrolina, PE, Brasil. Email: fernando.zocche@univasf.edu.br. Autor para correspondência.

"Departamento de Ciência e Tecnologia Agroindustrial, Laboratório de Microbiologia de Alimentos, Universidade Federal de Pelotas (UFPel), Pelotas, RS, Brasil. 
Em S. aureus, diversos genes codificadores de fatores de virulência estão presentes em elementos genéticos móveis, tais como ilhas de patogenicidade (SaPI), profagos e plasmídeos (JARRAUD et al., 2001). Dentre as quatro ilhas de patogenicidade descritas em S. aureus, SaPI3 tem grande importância por reunir genes de EE em um cluster denominado enterotoxin gene cluster ou cluster egc, o qual agrupa os genes codificadores de EEG(seg), EEI(sei), EEIM(selm), EEIN (seln) e EElO (selo), além de dois pseudogenes ( $\varphi$ ent1 $e$ $\varphi$ ent2), ainda sem função biológica determinada (JARRAUD et al., 2001; van BELKUM et al., 2006). Esse cluster é descrito por alguns autores (JARRAUD et al., 2001; THOMAS et al., 2006) como "berço" das EE, em que, a partir de eventos de recombinação genética, poderia ser formado um novo gene codificador de um superantígeno estafilocócico capaz de causar intoxicação alimentar. Além disso, a possibilidade de ocorrer transferência horizontal de genes de EE do cluster egc entre distintas cepas de $\boldsymbol{S}$. aureus também pode favorecer a evolução da bactéria e determinar o sucesso desse patógeno (JARRAUD et al., 2001; THOMAS et al., 2006).

Alimentos preparados com produtos de origem animal são os mais envolvidos em casos e/ou surtos de intoxicação alimentar estafilocócica (CENCIGOGA et al., 2003); portanto, a pesquisa de $\boldsymbol{S}$. aureus nesses alimentos e a avaliação de seu potencial em produzir enterotoxinas são fatores extremamente importantes na investigação epidemiológica e em análises de risco para essa doença (LANCETTE e BENNETT, 2001). Assim sendo, os objetivos deste estudo foram detectar, por PCR, genes pertencentes ao cluster egc em $\boldsymbol{S}$. aureus isolados em diferentes alimentos de origem animal, e relacionar sua presença com a fonte de isolamento.

\section{MATERIAL E MÉTODOS}

O isolamento e a identificação dos isolados de S. aureus nos alimentos (carne de frango, embutidos cárneos, leite cru, queijos) foram realizados de acordo com LANCETTE e BENNETT (2001), entre os anos de 2004 e 2008, na cidade de Pelotas, Rio Grande do Sul (RS). Dos 41 isolados, 14 foram oriundos de carne de frango, 14 de leite cru, oito de embutidos cárneos e cinco de queijo. As cepas de referência utilizadas foram S. aureus FRI361 e $\boldsymbol{S}$. aureus FRI472, as quais são portadoras dos genes-alvo deste estudo.

A extração de DNA genômico de $\boldsymbol{S}$. aureus foi realizada de acordo com o protocolo descrito por MATTHEWS et al. (1997), com modificações. Inicialmente, transferiu-se uma alçada de uma cultura de S. aureus em ágar Triptona Soja (TSA - Acumedia ${ }^{\circledR}$ ) incubada a $37^{\circ} \mathrm{C}$, por 24 horas, para $100 \mu \mathrm{L}$ de tampão Tris-EDTA (10mM Tris base e 5mM EDTA, pH 7,8) até turbidez 1,0 da escala de MacFarland. A lise do peptideoglicano celular ocorreu pela adição de $100 \mu \mathrm{L}$ de lisostafina $\left(100 \mu \mathrm{g} \mathrm{mL}^{-1}\right.$, Sigma $\left.{ }^{\circledR}\right)$ e incubação a $37^{\circ} \mathrm{C}$, em banho-maria, por 45 minutos. Para completar a lise celular, foram adicionados $20 \mu \mathrm{L}$ de tampão Tris-EDTA (50mM Tris base e $20 \mathrm{mM}$ de EDTA, pH 7,8) contendo $20 \%$ de dodecil sulfato de sódio (SDS) $\left(\right.$ Pharmacia $^{\circledR}$ ) e $3 \mu \mathrm{L}$ de proteinase $\mathrm{K}\left(20 \mathrm{mg} \mathrm{mL}^{-1}\right.$, Invitrogen $\left.{ }^{\circledR}\right) \mathrm{e}$ incubados em banho-maria, a $37^{\circ} \mathrm{C}$, por uma hora. Em seguida, foram adicionados $200 \mu \mathrm{L}$ de solução $\mathrm{NaCl} 5 \mathrm{M}$ e agitados manualmente, por 15 segundos. Separou-se o material intracelular por meio de centrifugação a 10.000x $\mathrm{g}$, por 15 minutos, a $4^{\circ} \mathrm{C}$, e transferiu-se o sobrenadante para um novo microtubo. Adicionou-se fenol-clorofórmio-álcool isoamílico $(25: 24: 1)$ para a liberação e separação de proteínas e, em seguida, centrifugou-se a $10.000 \mathrm{x}$, por 15 minutos, transferindose o sobrenadante para um novo microtubo. A precipitação do DNA foi realizada com $800 \mu \mathrm{L}$ de álcool etílico absoluto gelado, e a manutenção em $-20^{\circ} \mathrm{C}$ por, no mínimo, duas horas. Em seguida, foi realizada nova centrifugação a $10.000 \times \mathrm{g}$, por 15 minutos, a $4^{\circ} \mathrm{C}$, ressuspendendo-se o pellet com $30 \mu \mathrm{L}$ de água ultrapura estéril. A qualidade e a quantidade de DNA extraído foram estimadas por eletroforese em gel de agarose $1 \%$, comparando-se com o padrão de massa molecular DNA $\lambda /$ HindIII (Invitrogen ${ }^{\circledR}$ ).

Os oligonucleotídeos utilizados para amplificação dos fragmentos dos genes seg, sei, selm, seln e selo e para amplificação de um fragmento de $3375 \mathrm{pb}$ do cluster egc (denominado egc parcial) estão descritos na tabela 1 . Os oligonucleotídeos sei 1 e seg 2 (Tabela 1) foram desenhados para amplificar um fragmento de $3375 \mathrm{pb}$, o qual inclui as sequências

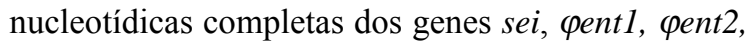
seln, além de 610 nucleotídeos do gene seg e 47 nucleotídeos do gene selm, utilizando-se uma PCR proposta por BLAIOTTA et al. (2004), com adaptações. As condições de reação foram: $12 \mathrm{pmol}$ de cada um dos oligonucleotídeos, 0,18mM de dNTP mix, 0,125mM de cloreto de magnésio, solução tampão para PCR contendo 2,5mM de $\mathrm{KCl}$ e 1,0mM de Tris- $\mathrm{HCl}(\mathrm{pH} \mathrm{8,4)}$, 2,5U de Taq DNA polimerase (Invitrogen ${ }^{\circledR}$ ) e água ultra pura esterilizada, totalizando $50 \mu \mathrm{L}$ por tubo. Quantidades entre 10 e 100ng de DNA foram utilizadas como molde para a PCR. A amplificação foi realizada em termociclador PTC - 100 (MJ Research - Peltier Thermal Cycler), com desnaturação do DNA a $95^{\circ} \mathrm{C}$, por três minutos, seguida de 30 ciclos $\left(95^{\circ} \mathrm{C} / 10\right.$ segundos, $72^{\circ} \mathrm{C}$ por 3,5 minutos) e de extensão final a 
Tabela 1 - Oligonucleotídeos iniciadores utilizados na detecção de genes do cluster egc e de um fragmento de 3375pb (egc parcial) em $\boldsymbol{S}$. aureus isolados de alimentos de origem animal.

\begin{tabular}{|c|c|c|c|c|}
\hline $\begin{array}{l}\text { Oligonucleotídeo/ } \\
\text { gene alvo }\end{array}$ & Sequência $5^{\prime} \rightarrow 3^{\prime}$ & Posição no cluster* & $\begin{array}{l}\text { Fragmentos } \\
\text { estimados }\left(\mathrm{pb}^{1}\right)\end{array}$ & Referência \\
\hline seg $1 /$ seg & TGCTATCGACACACTACAACC & $4758-4778$ & \multirow{2}{*}{704} & \multirow{4}{*}{$\begin{array}{l}\text { McLAUCHLIN et al. } \\
\qquad(2000)\end{array}$} \\
\hline $\operatorname{seg} 2 * * / \operatorname{seg}$ & CCAGATTCAAATGCAGAACC & $5461-5442$ & & \\
\hline sei $1 * * / s e i$ & GACAACAAAACTGTCGAAACTG & $2087-2108$ & \multirow{2}{*}{630} & \\
\hline sei $2 /$ sei & CCATATTCTTTGCCTTTACCAG & $2716-2695$ & & \\
\hline selm $1 /$ selm & CCAATTGAAGACCACCAAAG & $1544-1563$ & \multirow{2}{*}{517} & \multirow{6}{*}{ BLAIOTTA et al. (2004) } \\
\hline selm 2/selm & CTTGTCCTGTTCCAGTATCA & $2060-2042$ & & \\
\hline seln $1 /$ seln & ATTGTTCTACATAGCTGCAA & $3818-3837$ & \multirow{2}{*}{682} & \\
\hline seln $2 /$ seln & TTGAAAAAACTCTGCTCCCA & $4499-4480$ & & \\
\hline selo $1 /$ selo & AGTCAAGTGTAGACCCTATT & $494-513$ & \multirow{2}{*}{534} & \\
\hline selo $2 /$ selo & TATGCTCCGAATGAGAATGA & $1027-1008$ & & \\
\hline
\end{tabular}

*original accession number - AF285760 (Genbank); **sei 1 e seg 2: oligonucleotídeos utilizados para amplificação parcial de egc, correspondente a $3375 \mathrm{pb} ;{ }^{1} \mathrm{pb}=$ pares de base.

$72^{\circ} \mathrm{C}$, por sete minutos. Os produtos de PCR foram submetidos à eletroforese em gel de agarose $1 \%$ contendo brometo de etídeo e visualizados sob iluminação ultravioleta. O marcador de massa molecular utilizado foi o DNA $\lambda /$ HindIII (Invitrogen ${ }^{\circledR}$ ).

Para amplificação dos genes seg, sei, selm, seln e selo, utilizou-se PCR uniplex conforme protocolo previamente descrito por BLAIOTTA et al. (2004), com modificações. As condições de reação foram: $10 \mathrm{pmol}$ de cada um dos oligonucleotídeos (Tabela 1), 0,025mM de dNTP mix, 0,0625mM de cloreto de magnésio, solução tampão para PCR contendo $1,25 \mathrm{mM}$ de $\mathrm{KCl}$ e 0,5mM de Tris- $\mathrm{HCl}(\mathrm{pH} 8,4), 1 \mathrm{U}$ de Taq DNA polimerase (Invitrogen ${ }^{\circledR}$ ) e água ultra pura esterilizada, com volume final de $25 \mu \mathrm{L}$ por tubo. Quantidades entre 10 e $100 \mathrm{ng}$ de DNA foram utilizadas como molde para a PCR. As amplificações foram realizadas em termociclador PTC 100 (MJ Research, Peltier Thermal Cycler), desnaturando-se o DNA a $95^{\circ} \mathrm{C}$, por três minutos, seguido de 30 ciclos $\left(95^{\circ} \mathrm{C} / 10\right.$ segundos, $55^{\circ} \mathrm{C} / 75$ segundos) e de extensão final a $72^{\circ} \mathrm{C}$, por sete minutos. Os produtos de PCR foram submetidos à eletroforese em gel de agarose $1,2 \%$ contendo brometo de etídeo e visualizados sob iluminação ultravioleta. O marcador de massa molecular utilizado foi o 100pb DNA Ladder (Invitrogen $^{\circledR}$ ).

Os produtos de PCR obtidos com os oligonucleotídeos sei 1 e seg 2 a partir do DNA de $\boldsymbol{S}$. aureus FRI361 e S. aureus FRI472 foram purificados por GFX ${ }^{T M}$ PCR DNA and Gel Band Purification Kit (Amersham Biosciences ${ }^{\circledR}$ ) e digeridos individualmente com HindIII (Invitrogen ${ }^{\circledR}$ ) e EcoRI (Invitrogen ${ }^{\circledR}$ ). Inicialmente, digeriu-se o fragmento egc parcial com
HindIII, sendo utilizados $25 \mu \mathrm{L}$ de DNA purificado, $1 \mu \mathrm{L}$ de HindIII (20 unidades de enzima), $3 \mu \mathrm{L}$ do tampão recomendado pelo fabricante e específico para a enzima, água ultra pura esterilizada (q.s.p.) num volume final de $30 \mu \mathrm{L}$ e incubados a $37^{\circ} \mathrm{C}$, por duas horas. Em seguida, o produto foi novamente purificado por GFXTM PCR DNA and Gel Band Purification Kit e digerido com EcoRI, sendo utilizados $25 \mu \mathrm{L}$ de DNA purificado, $1 \mu \mathrm{L}$ de EcoRI (20 unidades de enzima), $3 \mu \mathrm{L}$ do tampão recomendado pelo fabricante e específico para a enzima, água ultra pura esterilizada (q.s.p.) num volume final de $30 \mu \mathrm{L}$ e incubados a $37^{\circ} \mathrm{C}$, por duas horas. Após a digestão com as duas enzimas, os fragmentos foram submetidos à eletroforese em gel de agarose $1 \%$ e comparados com o marcador de massa molecular GeneRuler 1kb DNA Ladder plus $\left(\right.$ Fermentas $^{\circledR}$ ).

Os resultados foram analisados por meio de análise de variância (ANOVA), e as possíveis diferenças $(\mathrm{P}>0,05)$ foram analisadas pelo teste de Tukey, utilizando-se o Programa Statistics 8.0 (STATSOFT, 2003).

\section{RESULTADOS E DISCUSSÃO}

A relação entre a presença do cluster egc e patogenicidade tem sido descrita em cepas de $\boldsymbol{S}$. aureus isoladas de fontes clínicas (van BELKUM et al., 2006) entretanto, com cepas isoladas em alimentos, o número de trabalhos é bastante reduzido (BANIA et al., 2006; HWANG et al., 2007; LAWRYNOWICZ-PACIOREK et al., 2007). Dessa forma, os objetivos foram avaliar a presença desse cluster em $\boldsymbol{S}$. aureus isolados em 
alimentos de origem animal e verificar se há correlação com a fonte de isolamento.

Os oligonucleotídeos iniciadores sei 1 e seg

2 foram específicos para o fragmento de $3375 \mathrm{pb}$ (egc parcial), o que pode ser comprovado por meio da digestão dos produtos de PCR com as enzimas EcoRI e HindIII, sendo obtidos fragmentos de $1654 \mathrm{pb}, 1085 \mathrm{pb}$ e 636pb, conforme descrito por JARRAUD et al. (2001) e BLAIOTTA et al. (2004). Os fragmentos gerados com a PCR e após a digestão podem ser observados na figura 1 .

O egc parcial mostrou-se um bom marcador da presença do cluster egc. Em 10 das 41 cepas avaliadas, houve amplificação do fragmento egc parcial e amplificação individual de cada um dos genes componentes do cluster. Além disso, nas outras cepas (31), não houve amplificação do fragmento egc parcial quando um ou mais genes estavam ausentes, como foi observado em três cepas que carreavam os genes seg, selm, seln e selo, em duas que possuíam o gene seln, e nas demais que não carreavam genes desse cluster. Os oligonucleotídeos iniciadores utilizados para amplificação de fragmentos dos genes seg, sei, selm, seln e selo foram específicos para os respectivos genes, conforme pode ser observado pelos produtos de PCR obtidos e mostrados na figura 1.

Na tabela 2, são apresentados os diferentes genótipos de $\boldsymbol{S}$. aureus quanto ao cluster egc em cepas isoladas em alimentos de origem animal, em Pelotas, RS. Verifica-se que houve diferença estatística significativa quanto à presença do cluster egc entre as cepas isoladas de carne de frango e aquelas isoladas de outras fontes. Dez cepas portavam o cluster egc completo (genes seg, sei, selm, seln e selo); entretanto, apenas uma (10\%) foi isolada em embutidos cárneos, índice semelhante ao relatado por BANIA et al. (2006), os quais, analisando 50 cepas de $\boldsymbol{S}$. aureus isoladas desses alimentos, encontraram 6\% com essa característica. As outras nove cepas (90\%) de S. aureus que portavam o cluster egc completo foram isoladas de carne de frango, porcentagem semelhante à relatada por SMYTH et al. (2005), que avaliaram 15 cepas de $\boldsymbol{S}$. aureus oriundas de frango e encontraram $86,7 \%$ das cepas carreando esses genes. Por outro lado, HWANG et al. (2007) caracterizaram molecularmente 87 cepas de S. aureus isoladas desse mesmo alimento e observaram que $36,9 \%$ possuíam egc completo. É interessante ressaltar que nesses três estudos todas as cepas provenientes de frangos possuíam o cluster completo, não havendo variantes genéticas quanto a essa característica, o que pode denotar a necessidade da presença simultânea dos cinco genes do cluster para um adequado estabelecimento de $\boldsymbol{S}$. aureus naquele hospedeiro e, consequentemente, para o provável desenvolvimento de patogenias. Outra hipótese que pode ser levantada é que, em frangos, há uma

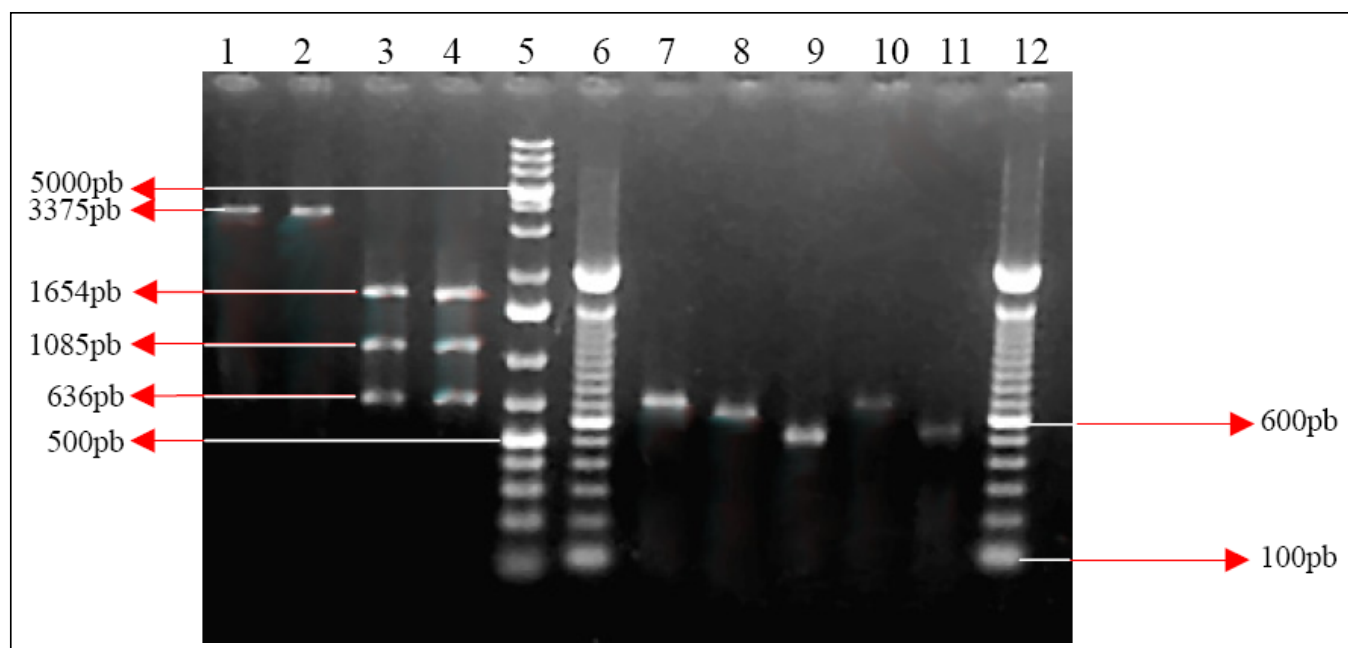

Figura 1 - Caracterização de genes do cluster egc em $\boldsymbol{S}$. aureus padrão e em isolados em alimentos de origem animal na cidade de Pelotas, RS: eletroforese em gel de agarose 1\% - Coluna 1: fragmento do cluster egc $(3375 \mathrm{pb})$ obtido a partir de DNA de $\boldsymbol{S}$. aureus FRI361 com oligonucleotídeos iniciadores sei $1 \mathrm{e}$ seg 2; Coluna 2: fragmento do cluster egc $(3375 \mathrm{pb})$ obtido a partir de DNA de $S$. aureus FRI472; Coluna 3: Fragmento do cluster egc obtido a partir de DNA de S. aureus FRI361, digerido com EcoRI e HindIII; Coluna 4: Fragmento do cluster egc obtido a partir de DNA de $\boldsymbol{S}$. aureus FRI472, digerido com EcoRI e HindIII; Coluna 5: Marcador de massa molecular GeneRuler 1kb DNA Ladder plus $\left(\right.$ Fermentas $^{\circledR}$ ); Colunas 6 e 12: Marcador de massa molecular Ladder 100pb (Invitrogen ${ }^{\circledR}$ ); Coluna 7: fragmento de seg $(704 \mathrm{pb})$; Coluna 8: fragmento de sei $(630 \mathrm{pb})$; Coluna 9: fragmento de selm $(517 \mathrm{pb})$; Coluna 10: fragmento de seln $(682 \mathrm{pb})$; Coluna 11: fragmento de selo $(534 \mathrm{pb})$. 
Tabela 2 - Distribuição e porcentagem dos diferentes genótipos do cluster egc em $\boldsymbol{S}$. aureus isolados em alimentos de origem animal na cidade de Pelotas, RS.

\begin{tabular}{|c|c|c|c|c|c|c|c|c|c|c|}
\hline \multirow[t]{2}{*}{ Genótipos } & \multicolumn{2}{|c|}{$\begin{array}{l}\text { Carne de frango } \\
\qquad\left(\mathrm{n}=14^{*}\right)\end{array}$} & \multicolumn{2}{|c|}{$\begin{array}{l}\text { Embutidos cárneos } \\
\qquad\left(\mathrm{n}=8^{*}\right)\end{array}$} & \multicolumn{2}{|c|}{ Queijo ( $\left.\mathrm{n}=5^{*}\right)$} & \multicolumn{2}{|c|}{ Leite cru $\left(\mathrm{n}=14^{*}\right)$} & \multicolumn{2}{|c|}{ Total $(n=41)$} \\
\hline & $\mathrm{n}$ & $\%$ & $\mathrm{n}$ & $\%$ & $\mathrm{n}$ & $\%$ & $\mathrm{~N}$ & $\%$ & $\mathrm{n}$ & $\%$ \\
\hline$e g c^{(-)^{* *}}$ & $5^{\mathrm{b}}$ & 35,8 & $4^{b}$ & 50 & $3^{b}$ & 60 & $14^{\mathrm{a}}$ & 100 & 26 & 63,4 \\
\hline$e g c^{(+)^{* * *}}$ & $9^{\mathrm{a}}$ & 64,2 & $1^{\mathrm{b}}$ & 12,5 & $-{ }^{b}$ & - & $-{ }_{-}^{b}$ & - & 10 & 24,4 \\
\hline seg, selm, seln, selo & $-\mathrm{b}$ & - & $1^{\mathrm{ab}}$ & 12,5 & $2^{\mathrm{a}}$ & 40 & $-{ }^{b}$ & - & 3 & 7,3 \\
\hline seln & $-\mathrm{b}$ & - & $2^{\mathrm{a}}$ & 25 & $-{ }^{b}$ & - & $-{ }^{b}$ & - & 2 & 4,9 \\
\hline
\end{tabular}

* Números amostrais seguidos pelas mesmas letras nas linhas não diferem entre si pelo teste de Tukey, com 5\% de probabilidade.

** não portadores de gene pertencente ao cluster egc.

*** portadores de todos os genes do cluster egc: seg, sei, selm, seln, selo.

distribuição clonal de $\boldsymbol{S}$. aureus que carreiam o cluster egc completo.

Cinco cepas albergavam um ou mais genes do cluster, mas não o egc completo. Uma cepa proveniente de embutidos cárneos e duas de queijos carreavam os genes seg, selm, seln e selo. Duas cepas, isoladas em embutidos, possuíam apenas o gene seln. Uma hipótese para a presença de cepas de $\boldsymbol{S}$. aureus com cluster egc incompleto é o alto nível de polimorfismo genético que esse cluster pode apresentar (BLAIOTTA et al., 2004; THOMAS et al., 2006). Um resultado interessante foi que três cepas (uma isolada em embutidos e duas em queijos) não carreavam o gene sei, embora o gene seg tenha sido detectado, haja vista que há controvérsias na literatura em relação à necessidade da coexistência desses genes em uma mesma cepa. JARRAUD et al., (2001) e NITZSCHE et al. (2007), por exemplo, descrevem que cepas que possuem um desses genes, necessariamente, carrearão o outro. CHEN et al. (2004) relatam que uma cepa de $\boldsymbol{S}$. aureus pode carrear o gene seg sem necessariamente possuir o gene sei, semelhantemente ao encontrado neste estudo. THOMAS et al. (2006) avaliaram 666 cepas clínicas de $\boldsymbol{S}$. aureus, encontrando apenas uma que não apresentava o gene sei e descrevem que nessa cepa havia dois tipos de sequência de inserção posicionados na região cromossômica onde deveria estar localizado esse gene. Esses autores sugerem que esse fenômeno ocorre quando parte do cluster egc é exportado ou inserido no cromossomo de cepas que estão passando por um processo de evolução gênica, e que, durante a transposição do material genético, pode ocorrer a integração total ou parcial de um gene não alvo. Embora essa hipótese não tenha sido testada neste estudo, há possibilidade de as cepas que não possuíam o gene sei serem cepas que estejam sofrendo ou já sofreram eventos de transposição de DNA.

É interessante salientar que, nas cepas isoladas em leite cru, não houve presença de genes do cluster egc. Outro estudo (ZOCCHE et al., 2009) conduzido no Rio Grande do Sul já havia demonstrado a baixa ocorrência de $\boldsymbol{S}$. aureus enterotoxigênicos nesse alimento, ao contrário do evidenciado em outras regiões brasileiras, como, por exemplo, em Pernambuco, onde STAMFORD et al. (2006) encontraram $77 \%$ de S. aureus enterotoxigênicos em leite in natura. Esses resultados vêm ao encontro de diversos estudos (CENCI-GOGA et al., 2003; NITZSCHE et al., 2007) que demonstraram alta variabilidade genética entre cepas de $\boldsymbol{S}$. aureus e que atribuem essa distinta enterotoxigenicidade a uma necessidade de adaptação do microrganismo ao ambiente e/ou hospedeiro. Por outro lado, duas cepas isoladas em queijo apresentaram cluster egc incompleto, o que faz supor que essas cepas tenham tido outra origem que não o leite. Uma provável fonte de contaminação pode ter sido os manipuladores de alimentos, uma vez que esses produtos sofrem alta manipulação após a pasteurização do leite, hipótese que pode ser corroborada pelo estudo de LAWRYNOWICZ-PACIOREK et al. (2007), os quais encontraram o cluster egc em $\boldsymbol{S}$. aureus isolados de fossas nasais de manipuladores de alimentos.

Observa-se, pelos diferentes genótipos encontrados, que o perfil enterotoxigênico das cepas de $\boldsymbol{S}$. aureus variou de acordo com o alimento de onde o microrganismo foi isolado, e houve relação entre a presença de determinados genes de EE e a procedência da bactéria $(\mathrm{P}>0,05)$, conforme pode ser observado pela tabela 2. A heterogeneidade genética observada pode ser explicada pela necessidade de a bactéria portar determinados genes, os quais favoreceriam seu 
estabelecimento em um hospedeiro e/ou alimento. Diversos trabalhos corroboram essa hipótese e descrevem um perfil toxigênico distinto e bastante amplo em S. aureus encontrados em alimentos de origem animal, como derivados lácteos (BLAIOTTA et al., 2004), embutidos cárneos (BANIA et al., 2006) e derivados de pescado (SIMON e SANJEEV, 2007), e em diversos animais, como bovinos, caprinos, ovinos, aves, coelhos (SMYTH et al., 2005; VIMERCATI et al., 2006) e suínos (NITZSCHE et al., 2007; HWANG et al., 2007).

\section{CONCLUSÃO}

Há presença de genes do cluster egc em $\boldsymbol{S}$. aureus isolados em alimentos de origem animal, na cidade de Pelotas, RS. Entretanto, diferentes genótipos podem ser observados de acordo com a sua fonte de isolamento $(\mathrm{P}>0,05)$. Em S. aureus isolados de frangos, a presença do cluster egc completo é elevada.

\section{AGRADECIMENTOS}

Ao Conselho Nacional de Desenvolvimento Científico e Tecnológico, processo 478100/04-3, pelo suporte financeiro; à Coordenadoria de Aperfeiçoamento de Pessoal de Nível Superior, pela concessão de bolsa PRODOC e à Márcia Magalhães Mata, pela análise estatística.

\section{REFERÊNCIAS}

BANIA, J. et al. Distribution of newly described enterotoxin-like genes in Staphylococcus aureus from food. International Journal of Food Microbiology, v.108, p.36-41, 2006. Disponível em: $<$ http://dx.doi.org/doi:10.1016/j.ijfoodmicro.2005.10.013>. Acesso em: 30 mar. 2010. doi: 10.1016/j.ijfoodmicro.2005.10.013.

BLAIOTTA, G. et al. PCR detection of staphylococcal enterotoxin genes in Staphylococcus spp. strains isolated from meat and dairy products. Evidence for new variants of $\mathrm{seG}$ and seI in S. aureus AB-8802. Journal of Applied Microbiology, v.97, p.719-730, 2004. Disponível em: <http://dx.doi.org/ doi:10.1111/j.1365-2672.2004.02349.x>. Acesso em: 30 mar. 2010. doi: 10.1111/j.1365-2672.2004.02349.x.

CENCI-GOGA, B.T. et al. Enterotoxin production by Staphylococcus aureus isolated from mastitic cows. Journal of Food Protection, v.66, p.1693-1696, 2003.

CHEN, T. R. et al. Use of novel PCR primers specific to the genes of staphylococcal enterotoxin G, H, I for the survey of Staphylococcus aureus strains isolated from food-poisoning cases and food samples in Taiwan. International Journal of Food Microbiology, v.92, p.189-197, 2004. Disponível em: <http:/ /dx.doi.org/doi:10.1016/j.ijfoodmicro.2003.10.002>. Acesso em: 30 mar. 2010. doi:10.1016/j.ijfoodmicro.2003.10.002.

EUZÉBY, J.P. List of bacterial names with standing in nomenclature. Disponível em: <http://www.bacterio.cict.fr/ s/staphylococcus.html >. On line. Acesso em: 06 set. 2009.
HWANG, S.Y. et al. Novel multiplex PCR for the detection of the Staphylococcus aureus superantigen and its application to raw meat isolates in Korea. International Journal of Food Microbiology, v.117, p.99-105, 2007. Disponível em: <http:/ /dx.doi.org/doi:10.1016/j.ijfoodmicro.2007.02.013>. Acesso em: 30 mar. 2010. doi:10.1016/j.ijfoodmicro.2007.02.013.

JARRAUD, S. et al. egc, highly prevalent operon of enterotoxin gene, forms a putative nursery of superantigens in Staphylococcus aureus. Journal of Immunology, v.166, p.669-677, 2001. Nota de correção em: Journal of Immunology, v.166, p.4260, 2001. Disponível em: <http:// www.jimmunol.org/cgi/content/full/166/1/669>. Acesso em: 30 mar. 2010 .

LANCETTE, G.A.; BENNETT, R.W. Staphylococcus aureus and staphylococcal enterotoxins. In. DOWNES, F.P.; ITO, K. Compendium of methods for the microbiological examination of foods. Washington: American Public Health Association (APHA), 2001. Cap.39, p.387-400.

LAWRYNOWICZ-PACIOREK, M. et al. The distribution of enterotoxin and enterotoxin-like genes in Staphylococcus aureus strains isolated from nasal carriers and food samples. International Journal of Food Microbiology, v.117, p.319323, 2007. Disponível em: <http://dx.doi.org/doi:10.1016/ j.ijfoodmicro.2007.03.009>. Acesso em: 30 mar. 2010. doi:10.1016/j.ijfoodmicro.2007.03.009.

MATTHEWS, K.R. et al. Identification and differentiation of coagulase-negative Staphylococcus aureus by polymerase chain reaction. Journal of Food Protection, v.60, p.686-688, 1997. Disponível em: <http://www.ingentaconnect.com/content/iafp/ jfp/1997/00000060/00000006/art00015>. Acesso em: 30 mar. 2010 .

McLAUCHLIN, J. et al. The detection of enterotoxins and toxic shock síndrome toxin genes in Staphylococcus aureus by polymerase chain reaction. Journal of Food Protection, v.63, p.479-488, 2000. Disponível em: $<$ http://www.ingentaconnect.com/content/ $\mathrm{iafp} / \mathrm{jfp} / 2000 / 00000063 / 00000004 / \mathrm{art} 00009>$. Acesso em: $30 \mathrm{mar}$. 2010 .

NITZSCHE, S. et al. Phenotypic and genotypic traits of Staphylococcus aureus strains isolated from pig carcasses. Veterinary Microbiology, v.120, p.292-299, 2007. Disponível em: <http://dx.doi.org/doi:10.1016/j.vetmic.2006.10.027>. Acesso em: 30 mar. 2010. doi:10.1016/j.vetmic.2006.10.027.

SIMON, S.S.; SANJEEV, S. Prevalence of enterotoxigenic Staphylococcus aureus in fishery products and fish processing factory workers. Food Control, v.18, p.1565-1568, 2007. Disponível em: <http://dx.doi.org/doi:10.1016/j.foodcont.2006.12.007>. Acesso em: 30 mar. 2010. doi:10.1016/j.foodcont.2006.12.007.

SMYTH, D.S. et al. Superantigen genes encoded by the egc cluster and SaPIbov are predominant among Staphylococcus aureus isolated from cows, goats, sheep, rabbits and poultry. Journal of Medical Microbiology, v.54, p.401-411, 2005. Disponível em: <http://dx.doi.org/doi:10.1099/jmm.0.458630>. Acesso em: 30 mar. 2010. doi:10.1099/jmm.0.45863-0.

STAMFORD, T.L.M. et al. Enterotoxigenicidade de Staphylococcus spp. isolados de leite in natura. Ciência e Tecnologia de Alimentos, v.26, p.41-45, 2006. Disponível em: 
<http://dx.doi.org/doi:10.1590/S0101-20612006000100007>. Acesso em: 30 mar. 2010. doi:10.1590/S010120612006000100007.

STATSOFT, INC. Statistica for Windows, Versão 8.0. Tulsa: StatSoft, 2003. Disponível em: <http://www.statsoft.com>. Online. Acesso em: 06 fev. 2010.

THOMAS, D.Y. et al. Staphylococcal enterotoxin-like toxins $\mathrm{U} 2$ and $\mathrm{V}$, two new staphylococcal superantigens arising from recombination within the enterotoxin gene cluster. Infection and Immunity, v.74, p.4724-4734, 2006. Disponível em: $<$ http://dx.doi.org/doi:10.1128/IAI.00132-06>. Acesso em: 30 mar. 2010. doi:10.1128/IAI.00132-06.

van BELKUM, A. et al. Clonal distribution and differential occurrence of the enterotoxin gene cluster, egc, in carriageversus bacteremia-associated isolates of Staphylococcus aureus.
Journal of Clinical Microbiology, v.44, p.1555-1557, 2006. Disponível em: <http://dx.doi.org/doi:10.1128/JCM.44.4.15551557.2006>. Acesso em: 30 mar. 2010. doi:10.1128/ JCM.44.4.1555-1557.2006.

VIMERCATI, C. et al. Molecular typing of Staphylococcus aureus. Journal of Veterinary Medicine, v.53, p.423-428, 2006. Disponível em: <http://dx.doi.org/doi:10.1111/j.14390450.2006.00980.x>. Acesso em: 30 mar 2010. doi:10.1111/ j.1439-0450.2006.00980.x.

ZOCCHE, F. et al. PCR multiplex para detecção de Staphylococcus aureus enterotoxigênicos isolados em alimentos de origem animal no sul do Rio Grande do Sul, Brasil. Interciencia, v.34, p.487-491, 2009. Disponível em: < http:/ /www.interciencia.org/v34_07/index.html>. Acesso em 30 mar. 2010 .

Ciência Rural, v.40, n.5, mai, 2010. 